\title{
The Tyrrhenian back-arc basin and subduction of the Ionian lithosphere
}

Dipartimento di Scienze della Terra e Geologico-Ambientali, University of Bologna, Via Zamboni 67, I-40127, Bologna, Italy. E-mail: contact capozzi@geomin.unibo.it

A deep, narrow, and distorted Benioff zone, plunging from the Ionian Sea towards the southern Tyrrhenian basin, is the remnant of a long and eastward migrating subduction of eastern Mediterranean lithosphere. From Oligocene to Recent, subduction generated the Western Mediterranean and the Tyrrhenian back-arc basins, as well as an accretionary wedge constituting the Southern Apenninic Arc.

In the Tyrrhenian Sea, stretching started in late Miocene and eventually produced two small oceanic areas: the Vavilov Plain during Pliocene (in the central sector) and the Marsili Plain during Quaternary (in the southeastern sector). They are separated by a thicker crustal sector, called the Issel Bridge. Back-arc extension was rapid and discontinuous, and affected a land locked area where continental elements of various sizes occurred. Discontinuities in extension were mirrored by changes in nature of the lithosphere scraped off to form the Southern Apenninic Arc. Part of the tectonic units of

\section{Introduction}

The Tyrrhenian and the Aegean Seas are back-arc basins connected to two Benioff zones (Calabrian and Aegean) indicating subduction of the Eastern Mediterranean lithosphere, an old, largely oceanic area. The Aegean trench and arc roughly trend E-W and here subduction reflects the N-S convergence between the African and European plates, as well as coaxial extrusion of Anatolia (Le Pichon and Angelier, 1979).

The Calabrian subduction system (Figure 1) is instead almost normal to the Aegean one and appears independent from the motion of the large plates. Here, subduction has been imputed, first by Ritsema 1979 (passive subduction) and subsequently by Malinverno and Ryan, 1986 (roll-back of subduction) to the slab pull of a retreating, old and dense oceanic lithosphere.

In this frame, the marine areas to the $\mathrm{W}$ of Italy represent a set of eastward younging back-arc basins. The Western Mediterranean basin formed from Oligocene to Middle Miocene at the rear of the Corsica-Sardinia continental block, which acted in the meantime as anti-clockwise rotating volcanic arc. Since late Miocene, back-arc extension resumed to the $\mathrm{E}$ of Sardinia, and the Tyrrhenian basin started forming.

the southern Apennines, accreted into the wedge from late Miocene to Pliocene, had originally been laid down on thinned continental lithosphere, which should constitute the deep portion of the present slab. After Pliocene, only Ionian oceanic lithosphere was subducted, because the large buoyancy of the wide and not thinned continental lithosphere of Apulia and Africa (Sicily) preserved these elements from roll back of subduction. After Pliocene, the passively retreating oceanic slab had to adjust and distort according to the geometry of these continental elements.

The late onset of arc volcanism in respect to the duration of extension in the Tyrrhenian-Ionian system may find an explanation considering an initial stage of subduction of thinned continental lithosphere. The strong Pleistocene vertical movements that occurred in the whole southeastern system (subsidence in the back-arc basin and uplift in the orogenic arc) may instead be related to the distortion of the oceanic slab.

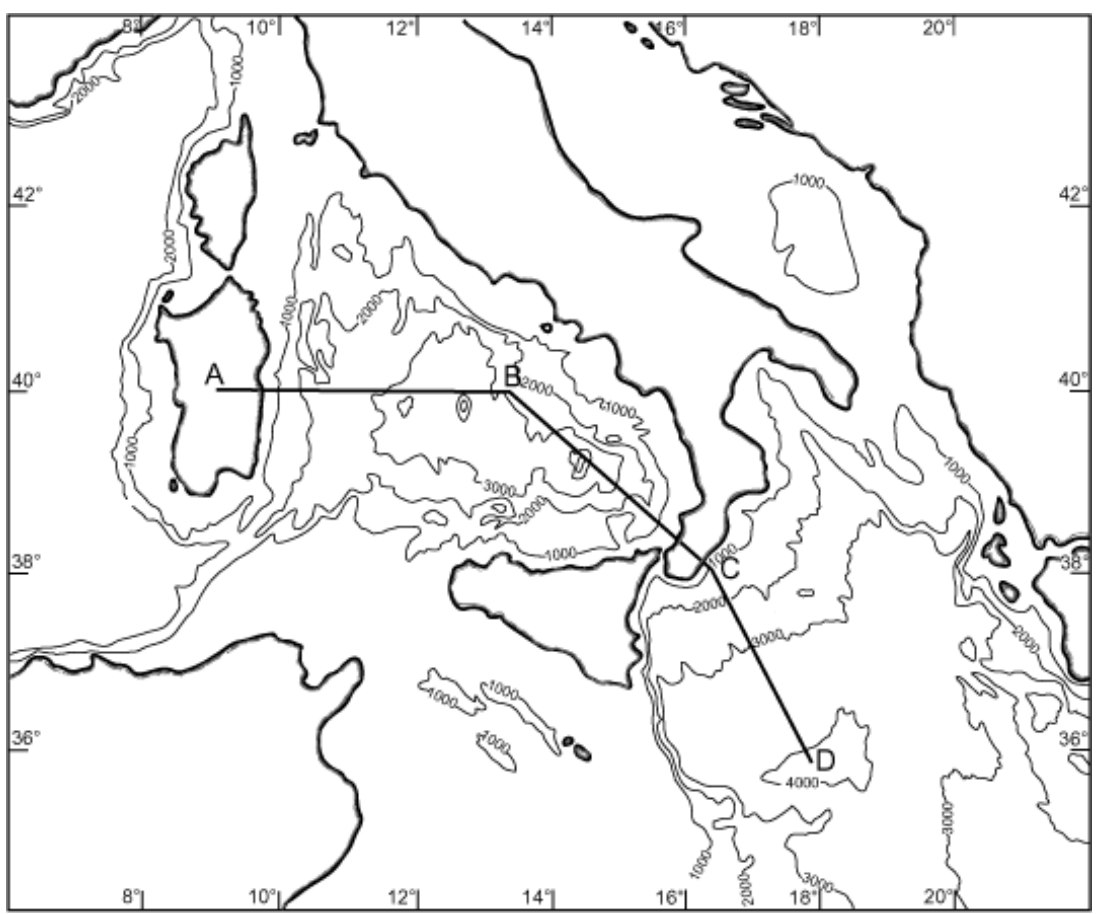

Figure 1 Location map of geological section across the Tyrrhenian to Ionian Seas (central Mediterranean) shown in Figure 3. 


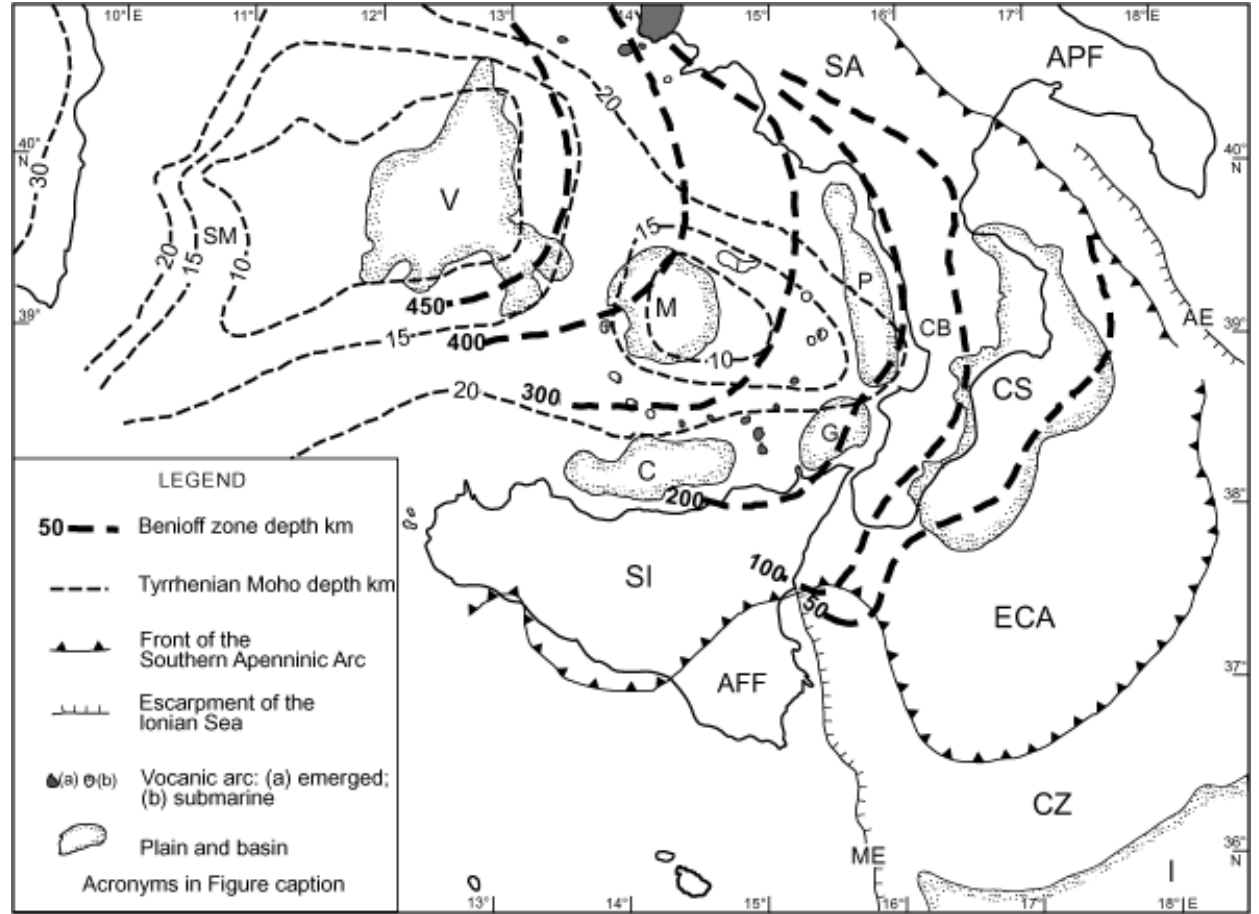

Figure 2 Moho depth and Benioff zone contours in the Tyrrhenian to Ionian area. Legend: $A E$, Apulian escarpment; AFF, African foreland; APF, Apulian foreland; C, Cefalù basin; CS, Crotone-Spartivento basin; CZ, Cobblestone zone; ECA, External Calabria Arc; G, Gioia basin; M, Marsili basin; ME, Malta escarpment; P, Paola basin; SA, Southern Apennines; SI, Sicily; SM, Sardinia margin; V, Vavilov basin.

Running with continuity from peninsular Italy to Sicily, the Southern Apenninic Orogenic Arc developed and migrated eastwards accompanying extension in the back-arc regions (see Vai and Martini, 2001, for an updated account on the Apennines). In respect to subduction processes, the arc behaved as upper plate or as offscraped tectonic wedge. The Southern Arc has migrated towards the Apulian (Southern Apennines) and African (Sicily) continental forelands; but also towards the deep marine areas off Calabria, where off-scraping of the Ionian lithosphere ("oceanic foreland?") is occurring (Figure 2).

This paper describes the present configuration of the Tyrrhenian-Ionian system; it tries to interpret, also on the base of data recently achieved in marine and emerged areas, the history of its progressive evolution during the last $10 \mathrm{Ma}$. It also takes into account some unusual features of the system, as a late development of arc volcanism and the onset of large vertical movements coupled to extension and shortening.

\section{The Ionian lithosphere and the Calabrian Benioff zone}

\section{Geometry and characters of subduction}

The Ionian Sea, NW portion of the Eastern Mediterranean, reaches some 4,100 m depth in the Messina Abyssal Plain and is bordered by two steep scarps $3 \mathrm{~km}$ high (Apulian and Malta Escarpments), where mostly Mesozoic carbonate sequences crop out (Bigi et al., 1991).

Nature and age of the crust in the deep Ionian basin are still a matter of debate. Refraction data (DeVoogd et al., 1992, with previous references) indicate either an oceanic or a thinned continental crust, depending on the location of seismic experiments. In addition, magnetic signature is poor and the basement is covered by several

\section{The trench-arc region}

$\mathrm{km}$ of sedimentary rocks. Across the borders of the basin, a crust transitional to normal continental (Africa and Apulia) occurs, but break-up unconformities do not crop out and, in addition, the present steep scarps were strongly reactivated during Neogene, so that they do not contain information as to the age of the oceanic crust in the Ionian basin. The proposed ages for this element span therefore from Permian to Tertiary (with cluster around late Mesozoic), depending on the various indirect criteria adopted (Catalano et al., 2000, with previous references).

At any rate, deep reflection seismic lines clearly image a flexing of the Ionian lithosphere beneath Calabria (Cernobori et al., 1996, with previous references) to join a seismogenic slab that extends down to some $500 \mathrm{~km}$ beneath the SE Tyrrhenian basin (Anderson and Jackson, 1987). This NW plunging Benioff zone is distorted, long $(700 \mathrm{~km})$ and narrow (less than $250 \mathrm{~km}$ ), abruptly disappearing laterally beneath the Apennines and Sicily (Ritsema, 1979; Gasparini et al., 1982). The depth reached by the Benioff zone (and the presence of a volcanic arc, see later) indicates that oceanic lithosphere has been subducted in this system.

A deep, continuous trench is not observed in the Ionian basin, as is the case for other converging margins carrying thick sediments. Where the Ionian basement starts plunging NW-ward, a gentle and irregular slope brings water depth from more than $4,000 \mathrm{~m}$ to less than $2,000 \mathrm{~m}$. The external portion of the slope (cobblestone zone in Figure 3 ) displays surficial deformations probably triggered by the presence of the Messinian evaporites. The major portion of the slope, named External Calabria Arc, hosts thrust systems, olistostromes, and possibly mud volcanoes, recalling an accretionary wedge (Rossi and Sartori, 1981; Finetti, 1982). Between the upper slope and Calabria, the wide Crotone-Spartivento fore-arc basin occurs. This is partly emerged, and its sedimentary sequences start with middle or upper Miocene (Rossi and Sartori, 1981).

Calabria is a sort of terrane largely made of Palaeozoic crystalline-metamorphic units assembled from Cretaceous till middle Miocene. This arc portion was bent and extended since Tortonian times, and experienced strong uplift (up to more than $1 \mathrm{~mm} / \mathrm{y}$ ) during Pleistocene. Inner to Calabria, but still fore of the volcanic arc, the Paola, Gioia, and Cefalù basins developed via extensional listric faults during or after Tortonian times, as parts of the eastern Tyrrhenian rifted margin (see later). The Paola basin shows a strong Pliocene-Quaternary subsidence, with thick sediments in part very gently folded. In the Gioia basin subsidence was largely Tortonian, while in the Cefalù basin, offshore Sicily, post-Tortonian stretching interplayed with wrench tectonics (Barone et al., 1982).

\section{The Southern Apenninic Arc}

Since Oligocene-Miocene, the continuous orogenic system forming the Southern Apenninic Arc was shortened while migrating towards the Apulian (Southern Apennines) and African (Sicilian Maghrebids) forelands, as well as towards the Ionian basin (Calabria and External Calabria Arc). The Tortonian to Recent part of this evolution is coeval with the development of the Tyrrhenian back-arc 
basin. Accepting that the units of the arc represent a tectonic wedge generated by off-scraping of the subducting slab, the pattern of arc shortening and migration should reflect the progressive deformation of the system. In the Southern Apennines, shortening and migration rates up to $6-8 \mathrm{~cm} / \mathrm{y}$ from Tortonian to Pliocene have been calculated, with Pleistocene shortening turned to sinistral strike-slip deformation (Patacca et al., 1992, 1993). Again with Pleistocene, large portions of the Southern Arc (including the Apulian foreland and Sicily) were affected by strong uplift. These observations call for a marked change in the deformation regime of the arc across the Pliocene-Pleistocene boundary.

\section{The volcanic arc}

The Eolian Islands are the volcanic arc of the converging system (Barberi et al., 1974). It is located in correspondence to a depth of the Benioff plane of about $250-300 \mathrm{~km}$ (Figure 3). The islands are part of a wider, largely submarine, ring-shaped complex of volcanic edifices whose activity started less than 1.7-1.5 Ma ago and still goes on in Stromboli Island and in other localities. Coeval arc type volcanism is typical of the whole south-eastern Tyrrhenian plain, including the large Marsili volcano, while manifestations of arc type older than Quaternary are quite rare elsewhere in the Tyrrhenian.

Slightly modified arc-type volcanism (Serri et al., 2001) also occurred since $2 \mathrm{Ma}$ and still is active (Vesuvius, etc.) in the Neaples-Phlegrean area, quite $\mathrm{N}$ of the Eolian Islands. This volcanism is located at the abrupt NE closure of the slab, where hypocenters suddenly pass from more than $400 \mathrm{~km}$ to crustal depths.

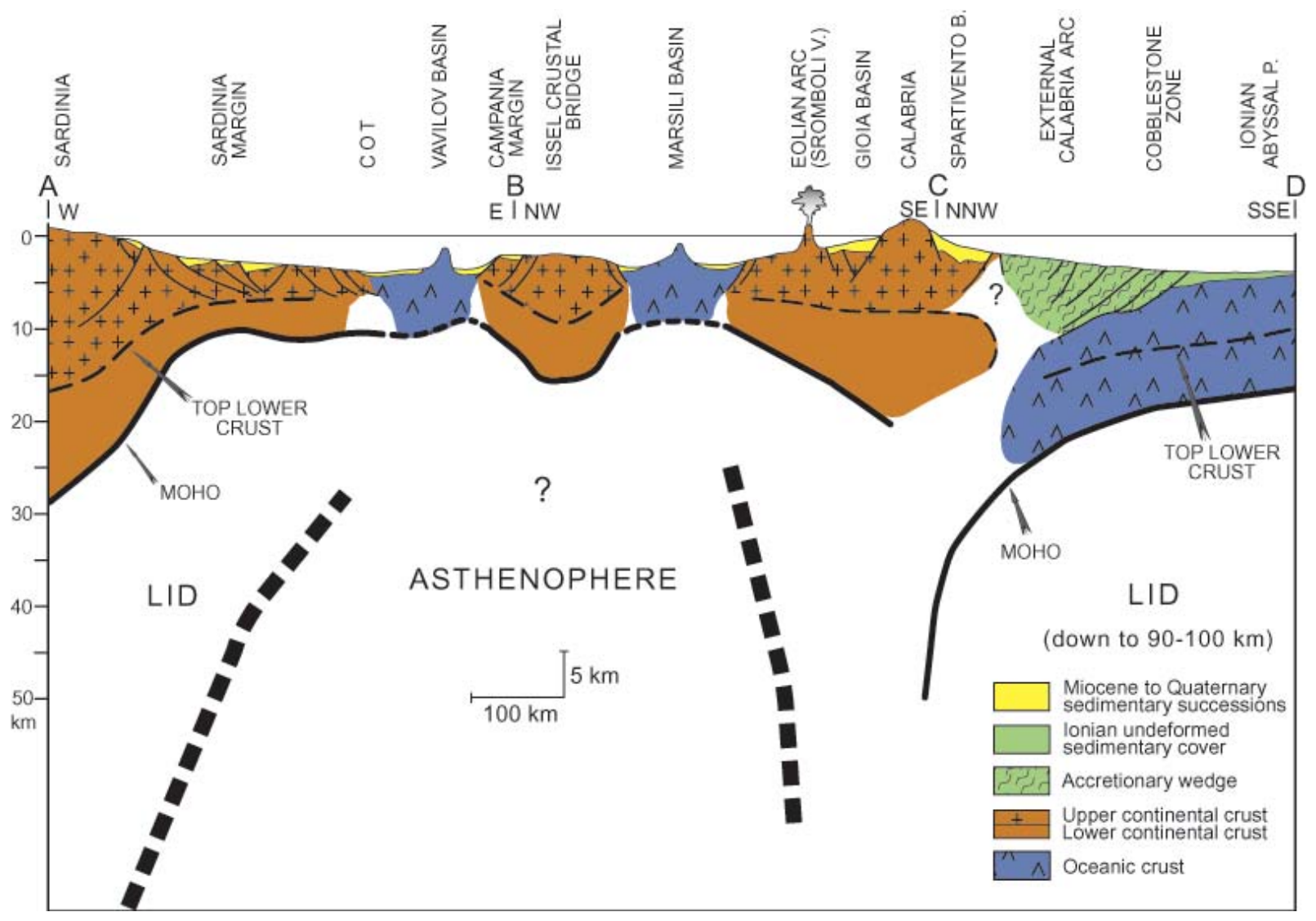

Figure 3 Crustal geological section (vertical exaggeration $\times 10$ ) and lithospheric/asthenopheric interpretation from Sardinia through the Tyrrhenian Sea, Calabria and the Ionian Sea.

\section{The southern Tyrrhenian back-arc basin}

\section{General characters}

The northern Tyrrhenian Sea, between Corsica and the Northern Apennines, is shallow, its crust is only moderately thinned, and its present evolution is not related to the Ionian subduction. The southern Tyrrhenian is included between Sardinia and the Southern Apenninic arc. It displays an irregular seafloor, marked by important seamounts, and reaches a depth of about 3,600 m. In two discrete areas, around the Vavilov and Marsili deep plains, MOHO depth is around $10 \mathrm{~km}$; and crustal thickness increases to $30 \mathrm{~km}$ and more towards the continental areas encircling the basin.

The southern Tyrrhenian was developed by stretching of an area previously occupied, from $\mathrm{W}$ to E, by the Sardinia continental block (Variscan basement), by the Europe-verging Alpine chain (Cretaceous-Paleogene) and by the portion of Apenninic arc formed from Oligocene to middle Miocene (Sartori, 1986). These early formed Apenninic units were generated by deformation of the Apulian and African margins during the development of the Western Mediterranean basin, in front of the rotating Corsica-Sardinia block.

\section{A poly-phase evolution}

\section{From Sardinia to the central Tyrrhenian}

Timing of rifting has been investigated across the Sardinia margin of the southern Tyrrhenian, during ODP Leg 107 (Kastens, Mascle et al., 1990). Lying north of a prominent lithospheric feature called Orosei Canyon Line (OCL) by Sartori et al. (2001) and occurring at about $40^{\circ} \mathrm{N}$ latitude, the upper portion of the margin was rifted from intra-Tortonian to mid-Messinian, while the lower one 
experienced stretching from mid-Messinian to lower Pliocene time. A wide continent-ocean transition (COT) was generated, with MOHO lying at $10 \mathrm{~km}$ depth beneath both the middle and lower faulted margin and the Vavilov plain (Sartori et al., 2001 and in press). In the central Tyrrhenian COT, extensional deformation rates were high, bringing crustal thickness from $30 \mathrm{~km}$ (or more) to 10 $\mathrm{km}$, in some $5 \mathrm{Ma}$. Abundant magmatism also accompanied stretching in the central Tyrrhenian. South of the OCL, rifting was continuous from Toronian to intra-Pliocene times and wider sectors of oceanic crust were generated in the southern Vavilov basin (Figure 3).

The areal distribution of oceanic crust (continent-ocean boundary) inside the central Tyrrhenian is not obvious: the COT is wide and linear magnetic anomalies are confuse or absent. In addition, the basin hosts huge volcanic and sub-volcanic bodies not related to spreading, whose seismic signature interplays with that of oceanic crust (Sartori et al., in press). The oceanic crustal domain in the central Tyrrhenian has a marked triangular shape and should be essentially of Pliocene age.

\section{From the central Tyrrhenian to the Southern Apenninic Arc}

A thicker $(15 \mathrm{~km})$ crustal sector, named Issel bridge, separates the Vavilov and the Marsili plains, where MOHO depth is again less than $10 \mathrm{~km}$. The Marsili basin has a rhombic shape and is located in the SE Tyrrhenian, just above the Ionian Benioff zone. It is included within the Eolian submerged ring of calcalkaline volcanics, with the huge Magnaghi calcalkaline volcano in the center, and should have been stretched essentially during Quaternary. It was also affected by strong (up to $1 \mathrm{~mm} / \mathrm{y}$ ) subsidence since its formation (Kastens, Mascle, et al., 1988).

Timing of rifting along the opposed narrow margins of peninsular Italy and of Sicily is not well constrained, although in most segments stretching had to predate Messinian and possibly interplayed with episodes of wrench deformation (see above).

Summarising age and trends of rifting-spreading evolution, a Tortonian to Pliocene episode of back-arc extension, when the Sardinia margin and the Vavilov plain were formed, indicates migration roughly from $\mathrm{W}$ to $\mathrm{E}$; a Pleistocene episode, when the Marsili basin was generated, indicates migration from NW to SE (Sartori and Capozzi, 1998).

\section{Discussion and conclusions}

The deep Benioff zone beneath Calabria witnesses a long period of slab retreat, characterized by grossly eastward migration, but punctuated, inside the back-arc regions, by interruptions and changes of extensional vectors. Roll-back of the slab begun during Oligocene, when stretching started in the Western Mediterranean back-arc basin. Here spreading stopped in middle Miocene, when rotation and arc volcanism ceased in Sardinia (Vigliotti and Langenheim, 1995). Back-arc extension resumed with Tortonian, jumping to the East of Sardinia. The Tyrrhenian basin then formed, with multistage rifting and with the eventual generation of two discrete oceanic areas, extended under different migration vectors.

Episodicity in back-arc development is observed in intraoceanic settings, as in the Western Pacific, due to changes in the configuration of the retreating slab with time. In the Mediterranean region, all land-locked, it is feasible that interruptions and changes in back-arc extension were produced by the interference of the retreating oceanic slab with intervening continental lithosphere.

In the Southern Apenninic tectonic wedge, palinspastic analyses point out that a carbonate platform was offscraped and included into the chain from late Miocene to Pliocene. These tectonic units are made up by Triassic to Miocene shallow water sequences, detached from a continental basement, since the platform was part of the inner Apulian continental margin of Tethys which experienced rifting during Mesozoic. External to this platform, but internal to a further carbonate platform making up the Apulian foreland of the chain, the passive margin of Tethys also included deep-water domains hosting at places basic volcanics. These basins, floored by thinned continental or oceanic crust, were included into the eastward migrating chain essentially during Pliocene. With Pleistocene, shortening ceased in the Southern Apennines and the tectonic regime turned to sinistral NW-SE strike-slip, accompanied by strong uplift of the whole orogenic system.

In the Tyrrhenian basin, after a Tortonian to middle Pliocene W to E directed stretching, which generated the Sardinia margin and the Vavilov plain, by the end of Pliocene extension rapidly turned to NW-SE and was limited to the southeastern Marsili plain.

Assuming that back-arc deformation and migration of the orogenic arc (accretionary wedge) were connected, we are forced to conclude that from Tortonian to Pliocene the sectors of thinned continental lithosphere, underlying the inner Apenninic carbonate platform, experienced subduction. With Pliocene-Pleistocene, it was instead Ionian-type oceanic lithosphere, branching possibly northwards in the deep-water areas located between the internal and the Apulian carbonate platforms, that was involved in subduction.

The Pliocene-Pleistocene changes in Tyrrhenian back-arc extension and in deformation of the Southern Apennines may reflect the resistance opposed to slab retreat by the wide Apulian and Sicilian (African) forelands. These elements were not thinned by the Mesozoic rifting and are characterized by normal continental lithosphere. During its eastward migration, passively retreating oceanic slab had to adjust and deform, in relation to the occurrence of these large and buoyant continental sectors. Post-Pliocene migration was therefore eventually driven only towards the narrow $(250 \mathrm{~km})$ corridor represented by the present Ionian Sea, largely oceanic in nature, and separating the Apulian from the African sectors.

This reconstruction implies that the present Benioff plain, although rather continuous at depth, has not a homogeneous oceanic nature, since its deep portion should consist of the thinned continental lithosphere that floored the inner carbonate platform of the Southern Apennines.

This hypothesis could explain the late onset of arc volcanism $(2-1.5 \mathrm{Ma})$ in respect to inception of back-arc extension in the Tyrrhenian basin (8-9 Ma), assuming that no foundered remnant arcs exist inside the system. Arc volcanism could not develop in the central Tyrrhenian area, produced by back-arc extension between Tortonian and intra-Pliocene, because in the meantime the thinned continental lithosphere underlying the inner Apenninic platform was subducted. This portion of the Tyrrhenian hosts abundant PliocenePleistocene volcanism, but this is essentially of Ocean Island Basalttype, with no influence from subduction (Serri et al., 2001; Sartori, in press).

Arc volcanism can only be triggered when oceanic lithosphere is subducting, and after it reaches at least some 100-150 km depth. With Pliocene, subduction affected the Ionian basin and the deepwater sectors of the Southern Apennines. Arc volcanism resumed in the system only when this oceanic lithosphere reached the depth necessary for magma generation. Due to the high velocity of slab retreat, this critical depth was reached towards the beginning of Pleistocene. At this time, back-arc extension was controlled by the not thinned continental sectors (present chain forelands), and migrated NW-SE into the Marsili basin. A calculation can be made taking an average dip of the Benioff plain of about $60-70^{\circ}$, and assuming that the age of inception of arc volcanism in the Eolian area (2-1.5 Ma) indicates the time when the oceanic portion of the subducting slab had reached $100-150 \mathrm{~km}$ depth. Since the Eolian volcanism is still active above a slab some $300 \mathrm{~km}$ deep, this would indicate a horizontal component of slab retreat (at constant dip) of some 100-120 km in 2 Ma, which is roughly the width of the Marsili basin. The derived NW-SE Pleistocene extensional rate of $5-6 \mathrm{~cm} / \mathrm{y}$ is well in line with deformation-migration rates calculated in the Southern Apennines (Patacca et al., 1992, 1993).

The present distortion of the slab should result from its different trends of retreat: W to E from Tortonian to Pliocene, and NW to SE afterwards (see also Ritsema, 1979), implying that the geometry of the subducting slab can adjust rapidly (in less than $2 \mathrm{Ma}$ ) to changes 
in the boundary conditions dictated by the occurrence of large, normal continental lithosphere. This is not surprising considering the high deformation rates shown by this land-locked system. A working hypothesis is that the large Pleistocene vertical movements, observed in the Southern Apenninic Arc (uplift) and in the Marsili plain (subsidence) are related to slab distortion. The subsidence in the Marsili plain (up to more than $1 \mathrm{~mm} / \mathrm{y}$ ) is much higher than expected by thermal cooling of the oceanic crust and is the same order of magnitude of the uplift in the Southern Apenninic Arc. Observing that the arc lies on the convex part of the distorted slab while the Marsili plain corresponds to the concave one (see hypocentral isobaths in Figure 2), it is tempting to relate such opposed vertical movements to Pleistocene slab distortion.

\section{Acknowledgments}

L. Torelli (Parma Univ.), N. Zitellini and G. Carrara (IGM-CNR Bologna), J. Mascle (Villefranche-sur-Mer), G. Brancolini (OGS, Trieste) are gratefully thanked for the long and fruitful collaboration on geology of the Tyrrhenian basin. Research funded by MURST 40\% (1998-2000) and RFO grants (Bologna Univ.).

\section{References}

Anderson, H., and Jackson, J., 1987, The deep seismicity of the Tyrrhenian Sea: Geophysical Journal International, v. 91, pp. 613-637.

Barberi, F., Innocenti, F., Ferrara, G. et al., 1974, Evolution of Eolian arc volcanism: Earth and Planetary Science Letters, v. 21, pp. 269-276.

Barone, A., Fabbri, A., Rossi, S., and Sartori, R., 1982, Geological structure and evolution of the marine areas adjacent to the Calabrian arc: Earth Evolution Sciences, v. 3, pp. 207-221.

Bigi, G., Cosentino, D., Parotto, M., Sartori, R., and Scandone, P., 1991, Structural Model of Italy: Sheet n. 6, scale 1:500.000, Progetto Finalizzato Geodinamica CNR, Quaderni Ricerca Scientifica, v. 3, n. 114.

Catalano, R., Franchino, A., Merlini, S., and Sulli, A., 2000, A crustal section from the Eastern Algerian basin to the Ionian ocean (Central Mediterranean): Memorie della Società Geologica Italiana, v. 55, pp. 71-85.

Cernobori, L., Hirn, A., McBride, J. H., et al., 1996, Crustal image of the Ionian basin and its Calabrian margins: Tectonophysics, v. 264, pp. 175-189.

DeVoogd, B., Truffert, C., Chamot-Rooke, N., Huchon, P., Lallemant, S., and Le Pichon, X., 1992, Two-ship deep seismic soundings in the basins of the Eastern Mediterranean Sea (Pasiphae cruise): Geophysical Journal International, v. 109, pp. 536-552.

Finetti, I., 1982, Structure, stratigraphy and evolution of the Mediterranean Sea: Bollettino Geofisica Teorica Applicata, v. 15, pp. 263-341.

Gasparini, P., Iannaccone, G., Scandone, P., and Scarpa, R., 1982, Seismotectonics of the Calabrian Arc: Tectonophysics, v. 84, pp. 267-286.

Kastens, K.A., Mascle, J., Auroux, C., et al., eds., 1990, Proceedings ODP Scientific Results, 107, College Station, Texas (Ocean Drilling Program), $772 \mathrm{pp}$.

Kastens, K.A., Mascle, J., and ODP Leg 107 scientific party, 1988, ODP Leg in the Tyrrhenian Sea: insight into passive margin and back-arc basin evolution: Geological Society of America Bullettin, v. 100, pp. 11401156.

Le Pichon, X., and Angelier, J., 1979, The Hellenic arc and trench system: a key to the neotectonic evolution of the eastern Mediterranean region: Tectonophysics, v. 60, pp. 1-42.

Malinverno, A., and Ryan, W.B.F., 1986, Extension in the Tyrrhenian Sea and shortening in the Apennines as a result of arc migration driven by sinking of the lithosphere: Tectonics, v. 5, pp. 227-245.

Patacca, E., Sartori, R., and Scandone, P., 1992, Tyrrhenian basin and Apenninic arcs: Kinematic relations since Late Tortonian times: Memorie Società Geologica Italiana, v. 45, pp. 425-451.

Patacca, E., Sartori, R., and Scandone, P., 1993, Tyrrhenian Basin and Apennines: Kinematic evolution and related dynamic constraints, in Boschi, E., Mantovani, E., and Morelli A., eds., Recent evolution and seismicity of the Mediterranean Region: Dordrecht, Kluwer Academic Publishers, pp. 161-171.

Ritsema, A.R., 1979, Active or passive subduction at the Calabrian Arc, in Van der Linden, W.J.M., ed., Fixism, mobilism or relativism: Van Bemmelen's search for harmony: Geologie en Mijnbouw, v. 58, pp.127-134.
Rossi, S., and Sartori, R., 1981, A seismic reflection study of the External Calabrian Arc in the Northern Ionian Sea (Eastern Mediterranean): Marine Geophysical Research, v. 4, pp. 403-426.

Sartori, 1986, Notes on the geology of the acustic basement in the Tyrrhenian Sea: Memorie Società Geologica Italiana, v. 36, pp. 99-108.

Sartori, R., and Capozzi, R., 1998, Patterns of Neogene to Recent rift-related subsidence in the Tyrrhenian domain, in Cloetingh, S., Ranalli, G., and Ricci, C.A., eds., Sedimentary Basins-Models and Constraints: Proceedings of the International School on Earth and Planetary SciencesCNR, Siena, pp. 147-158.

Sartori, R., Carrara, G., Torelli, L., and Zitellini, N., 2001, Neogene evolution of the southwestern Tyrrhenian Sea (Sardinia Basin and western Bathyal Plain): Marine Geology, v. 175, pp. 47-66.

Sartori, R. Torelli, L., Zitellini, N., Carrara, G., Magaldi, M., and Mussoni, P., The Neogene bathyal plain in the central Tyrrhenian Sea: crustal characters of an embryonic back-arc basin: submitted to Tectonophysics (in press).

Serri, G., Innocenti, F., and Manetti, P., 2001, Magmatism from Mesozoic to Present: petrogenesis, time-space distribution and geodynamic implications, in Vai, G.B., and Martini, I.P., eds., Anatomy of an Orogen: the Apennines and Adjacent Mediterranean Basins: Dordrecht, Kluwer Academic Publishers, pp. 77-103.

Vai, G.B., and Martini, I.P., eds., 2001, Anatomy of an Orogen: the Apennines and Adjacent Mediterranean Basins. Dordrecht, Kluwer Academic Publishers, $632 \mathrm{pp}$.

Vigliotti, L., and Langenheim, V.E., 1995, When did Sardinia stop rotating? New paleomagnetic results: Terra Nova, v. 7, pp. 424-435.

The late Renzo Sartori was Professor of Marine Geology at the Bologna University (Italy), where he got a Laurea in Geological Sciences in 1970. He participated several cruises in the Mediterranean Sea and in the Atlantic and Pacific Oceans, including DSDP Leg 59 and ODP Leg 107. In ODP, he served as member of EXCOM and SSP; he also chaired the European Consortium (ECOD) Management Committee for ODP (EMCO). He was author or co-author of more than 100 research papers and geological maps, mainly related to the various sub-basins of the Mediterranean and to Equatorial Pacific and Eastern Atlantic areas.

Renzo Sartori passed away on January 5, 2003, in Bologna. With his passing the geological fraternity has lost an excellent geologist and a fine gentleman.

— The Editor of this Special Issue 